\title{
Scyphocephalione a Isolated from the Stem Bark of Scyphocephalium Ochocoa (Myristicaceae) Attenuate Acute and Chronic Pains Through the Antiinflammatory Activity
}

Marius Mbiantcha ( $\nabla$ mbiantchamarius@yahoo.fr)

Universite de Dschang Faculte des Sciences https://orcid.org/0000-0001-8586-6150

Raymond Tchouya Guy Feuya

Université des Sciences et Techniques de Masuku: Universite des Sciences et Techniques de Masuku

William Nana Yousseu

Université de Dschang: Universite de Dschang

Donatien Albert Atsamo

Université de Yaoundé I: Universite de Yaounde I

Hibrahim Foundikou

Université des Sciences et Techniques de Masuku: Universite des Sciences et Techniques de Masuku Jacques Lebibi

Université des Sciences et Techniques de Masuku: Universite des Sciences et Techniques de Masuku

Franklin Gamo Zemo

Université de Yaoundé I: Universite de Yaounde I

\section{Research Article}

Keywords: Scyphocephalium ochocoa, Scyphocephalione A, Neuropathic pain, Acute pain

Posted Date: January 3rd, 2022

DOI: https://doi.org/10.21203/rs.3.rs-1211982/v1

License: (c) (1) This work is licensed under a Creative Commons Attribution 4.0 International License.

Read Full License 


\section{Abstract}

\section{Abstract}

In the treatment of cancer, patients that receive anti-cancer drugs such as Vincristine develop peripheral neuropathic pain. Scyphocephalione A is a new bioactive compound isolated from Scyphocephalium ochocoa (Myristicaceae), a medicinal plant traditionally used in African countries. Recently, an in vitro study has shown its anti-inflammatory and cytotoxic activities on MCF-7 cell line of mammary carcinoma. The purpose of the present study was to assess the in vitro anti-inflammatory and in vivo anti-nociceptive activities of Scyphocephalione A. In vitro tests were carried out on cyclooxygenase and 5lipoxygenase activities, and on protein denaturation; while in vivo tests were performed on acute and chronic pain models. It was noticed that, Scyphocephalione A $(1000 \mu \mathrm{g} / \mathrm{ml})$, inhibits proteins denaturation, cyclooxygenase and 5-lipoxygenase activities respectively by $74.21 \%, 75.80 \%$ and $64.43 \%$. The dose $50 \mathrm{mg} / \mathrm{kg}$ of Scyphocephalione A, inhibits acetic acid $(63.43 \%, \mathrm{p}<0.001)$ and formalin $(42.12 \%$ $(p<0.001)$ within first phase and $67.53 \%(p<0.001)$ within second phase)-induced pains. At the same dose, Scyphocephalione A significantly inhibited mechanical and heat hyperalgesia, as well as cold allodynia induced by vincristine. In addition, the compound restored haematological, biochemical and oxidative stress parameters which were altered following Vincristine administration. These results suggest that Scyphocephalione $A$ is endowed with anti-inflammatory potential and antinociceptive properties. Therefore, Scyphocephalione A can be classified as a promising molecule for the management of peripheral neuropathic pain triggered by anti-cancer drug.

\section{Introduction}

Acute pain is a red flag that alerts the body to some dysfunction or condition, while chronic pain is a disease which usually occurs following nerves damage. Pain affects more than $72.4 \%$ of the world's population (Besson 1999; Thomas et al. 2004). Neuropathic pain is one of the most common chronic pain which is typically observed in patients with multiple sclerosis (Mori et al. 2010), viral infection (Hewitt et al. 1997), diabetes mellitus (Davis et al. 1977), stroke (Kumar and Soni 2009), cancer chemotherapy (Han and Smith 2013) and also persistent post-surgical pain (Kehlet et al. 2006). In addition, patients under treatments with anti-cancer drugs such as Paclitaxel, Vincristine and/or Cisplatin develop peripheral neuropathic pain (Scripture et al. 2006; Joseph and Levine 2009; Gomber et al. 2010).

Although considered to be very neurotoxic, Vincristine is widely used as an antineoplastic agent against blood cancers and against solid tumours (Airiau 1999; Windebank 1999). It is well known that administration of Vincristine in rats induces peripheral neuropathy (Authier et al. 2003; Kahng et al. 2015). This substance has a great affinity with the tubulin of the microbubbles and induces functional and structural alterations of peripheral nerve fibre (Authier et al. 2003). Clinically, apart from stopping all ongoing anti-cancer treatments, there is no truly established treatment for peripheral neuropathy (Boyle et al. 1996). More than $50 \%$ of patients treated with Vincristine, developed sensorimotor neuropathy and the variation in sensitivity varies with the doses used (Authier et al. 2003). The current clinical strategy in the 
management of peripheral neuropathy is the use of anticonvulsants (gabapentin), analgesics (tramadol) and/or antidepressants (amitriptyline) (Van den Bent 2005; Dworkin et al. 2010), though these treatments have low efficacy and severe side effects ((Van den Bent 2005). An alternative could be to have a compound which can express anti-cancer effects and prevent or do not induce peripheral neuropathy.

Several studies have shown the great capacity of plants used in traditional African medicine to provide many biologically active compounds that fight against several diseases. This is the case of Tabebuia pallida which has shown apoptotic and antioxidant properties (Rahman et al. 2021), Ophiorrhiza rugosa which developed peripheral and central analgesic effects (Uddin Chy et al. 2021), Spirulina platensis which has antinociceptive effects through acting on the opiod system and TRPM8/TRPA1 channels (Freitas et al. 2021), extracts of Aglaonema hookerianum which have antidepressant, anxiolytic and aphrodisiac potential (Goni et al. 2021) and Amburana cearensis which has pharmacological and neuroprotective properties (Silva et al. 2020). Similarly, many compounds derived from plants have proven their effectiveness, such as Cannabis (Gonçalves et al. 2020), Coumarins (Küpeli Akkol et al. 2020), Terpineol (Vieira et al. 2020) or Cannabidiol (Martínez et al. 2020). Our interest focused on Scyphocephalium ochocoa (S. ochocoa), a plant of the Myristicaceae family, found in West Africa (tropical region) (Doyle et al. 2008). S. ochocoa is a well-known traditional medicinal plant, widely used in the central Africa folk medicine for the treatment of many diseases including respiratory tract infections, general fatigue, abscesses, tuberculosis, anaemia, kidney and breast cancer (Feuya Tchouya et al. 2015; Ngoua-Meye-Misso et al. 2019). Pharmacological studies showed that S. ochocoa possessed antiradical, antimicrobial, anti-inflammatory, anti-angiogenic and antioxidant properties (Feuya Tchouya et al. 2015; Ngoua-Meye-Misso et al. 2019; Feuya Tchouya et al. 2021).

Furthermore, Foundikou et al. (2018), isolated from leaves of S. ochocoa three alkyl resorcynols and two pentacyclic triterpenes. Previous work carried out on the stem-bark of $S$. ochocoa resulted in the isolation and characterization of a new dibenzofuran derivative called Scyphocephalione A. Biological evaluation showed that this compound possessed immunomodulatory, anti-inflammatory and cytotoxic properties against the MCF-7 cell line of mammary carcinoma (Feuya Tchouya et al. 2021). Thus, the present study aims to evaluate in vitro anti-inflammatory and in vivo anti-nociceptive activities of Scyphocephalione A.

\section{Methods}

\section{Reagents, Chemicals and Equipment.}

Different reagents and chemicals used in this study were procured from various sources: Morphine was purchased from Sigma Aldrich (St. Louis, MO, USA); Sodium nitroprusside from Merck Ltd (Mumbai, India); Trypsin and Casein from Hi-Media Lab. Ltd. (Mumbai, India). Sulfanilamide, Sodium hydroxide, Linoleic acid, Phosphoric acid, Ascorbic acid, Sulfuric acid, Arachidonic acid and Sodium linoleate were purchased from SD Fine Chem. Ltd, (Mumbai, India); Hemoglobin, Thiobarbituric acid, Ethylenediaminetetra acetic acid, Bovine albumin and Lipopolysaccharide were from Central Drug House Pvt. Ltd., (New Delhi, India); Dimethyl sulfoxide (DMSO) and Sodium chloride from Geochim Sarl. 
(Western region, Cameroon); Diclofenac sodium, Ibuprofen, Vitamin C, Indomethacin and other reagents were provided from local suppliers in Pakistan.

To assess neuropathic pain, mechanical hyperalgesia (analgesimeter, UGO Basil, Italy), thermal hyperalgesia (Hotplate, Ugo Basile, Monvalle VA, Italy) and cold allodynia (cold water $\left(4^{\circ} \mathrm{C}\right)$ ) equipment were used.

\section{Plant Material, Extraction and Isolation.}

The whole plant of Scyphocephalium: ochocoa, was collected in Franceville, Upper Haut Ogooue Province, South-East of Gabon, then identified by a botanist from the National Herbarium of Gabon (M. Yves Issembe) by comparing it with a preserved specimen under the number So 083/UM. The bark was removed, sliced up, shade dried and crushed (Feuya Tchouya et al. 2021). Thus, $3.5 \mathrm{~kg}$ of powder was macerated in $7 \mathrm{~L}$ of a mixture of dichloromethane (DCM)/methanol (MeOH) (1:1) and kept at room temperature during $72 \mathrm{~h}$. After filtration and concentration in a rotary evaporator, a new extraction of the residual powder was carried out and the various crude extracts were mixed. The final concentrate was dried (under vacuum) to give $250 \mathrm{~g}$ ( $7.14 \%$ yield) of crude extract. It was dissolved in a $\mathrm{MeOH} / \mathrm{H}_{2} \mathrm{O}$ mixture (1:1), then successively extracted with $n$-hexane and with ethyl acetate. Extraction of each mixture was carried out in vacuum to give $41.5 \mathrm{~g}$ of $\mathrm{n}$-hexane extract ( $16.6 \%$ yield), $45 \mathrm{~g}$ of ethyl acetate extract ( $18 \%$ yield) and $95 \mathrm{~g}$ of aqueous residue (38\% yield). The hexane extract ( $30 \mathrm{~g}$ ) was subjected to column chromatography (silica gel, n-hexane/ethyl acetate of increasing polarity), which gave $0.875 \mathrm{~g}$ of Scyphocephalione A (2.92 \% yield) at an n-hexane/ethyl acetate polarity of 90:10 (Feuya Tchouya et al. 2021).

\section{In vitro assays.}

\section{Anti-inflammatory Activity}

The evaluation of the anti-inflammatory properties of Scyphocephalione A was done following the in vitro cyclooxygenase activity and 5-Lipoxygenase activity inhibition tests as well as the in vitro protein denaturation technic. The methods described by Djuichou Nguemnang et al. (2019) and Mbiantcha et al. (2020) were used.

\section{Preparation of lymphocyte culture.}

A culture (human peripheral lymphocytes, RPMI 1640 (HIMEDIA), streptomycin, penicillin, fetal calf serum, phytohemagglutinin (HIMEDIA)), was filtered using cellulose acetate $0.2 \mu \mathrm{m}$ pore brand Sartorios. After addition of $1 \times 10^{6}$ cells $/ \mathrm{ml}$ of plasma, the culture was incubated for $72 \mathrm{~h}$. After another addition of $1 \mu \mathrm{l}$ of lipopolysaccharide and a $24 \mathrm{~h}$ incubation period, the culture received different concentrations (100, 200, 500 and $1000 \mu \mathrm{g} / \mathrm{mL}$ ) of Scyphocephalione A, Diclofenac and Ibuprofen, then incubated again for $24 \mathrm{~h}$. The culture was next centrifuged for $10 \mathrm{~min}$ at $6000 \mathrm{rpm}$, followed by removal of the supernatant 
and addition of $50 \mu \mathrm{l}$ of lysis buffer. Finally, the culture was centrifuged again as previously described (Viji, and Helen 2008).

\section{Assay of Cyclooxygenase, 5-Lipoxygenase and Protein Denaturation Inhibition.}

A mixture of Tris- $\mathrm{HCl}$ buffer, cyclooxygenase, hemoglobin, glutathione, arachidonic acid and TCA (10 \% in $\mathrm{HCl} 1 \mathrm{~N}, 0.2 \mathrm{ml})$, was incubated at $37^{\circ} \mathrm{C}$ for $20 \mathrm{~min}$. Then after addition of TBA $(0.2 \mathrm{ml})$, it was heated with boiling water for 20 minutes, cooled and then centrifuged for 3 minutes at $1000 \mathrm{rpm}$. The supernatant was used to assess cyclooxygenase activity at $632 \mathrm{~nm}$ (Viji, and Helen 2008).

To assess 5-lipoxygenase activity, the starting mixture $(25 \mathrm{ml})$ consisting of linoleic acid $(70 \mathrm{mg})$, Tween 20 ( $4 \mathrm{ml}$ of non-oxygenated water), sodium hydroxide $(0.5 \mathrm{~N})$ and non-oxygenated water was divided into portions ( $0.5 \mathrm{ml}$ each). Each portion was rinsed with nitrogen, frozen and passed into a quartz cuvette at $25^{\circ} \mathrm{C}$. A control solution, prepared from $0.2 \mathrm{ml}$ of sodium linoleate, $2.75 \mathrm{ml}$ of Tris buffer ( $\mathrm{pH} \mathrm{7.4)}$ and 50 $\mathrm{ml}$ of enzyme was used. The optical density (OD) was measured at $234 \mathrm{~nm}$ (Viji, and Helen 2008) and the percentage (\%) of inhibition was calculated as follow:

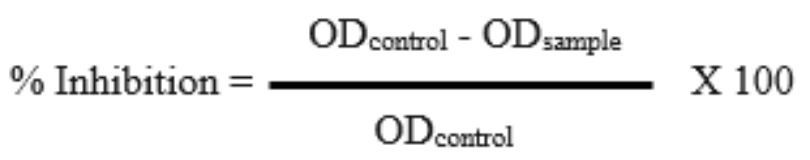

In a solution $(1 \mathrm{ml})$ containing distilled water (control tube), Diclofenac or Scyphocephalione A at different concentrations $(100,200,500$ and $1000 \mu \mathrm{g} / \mathrm{ml})$, the bovine serum solution $(1 \mathrm{ml}, 5 \%)$ was added. The mixture was incubated $\left(15 \mathrm{~min}, 27^{\circ} \mathrm{C}\right)$ and placed at $70^{\circ} \mathrm{C}(10 \mathrm{~min})$. After cooling (room temperature), the OD was measured at $660 \mathrm{~nm}$ (Padmanabhan and Jangle 2012) and the percentage of inhibition was calculated using the same formula presented above.

\section{In vivo assays}

\section{Experimental animals}

To performed all tests, adult male and female mice (Mus musculus, BALB/c) and rats (Wistar) of 3 months old and, weighing on average $27 \pm 1$ (mice for acute pain assay) and $170 \pm 2 \mathrm{~g}$ (rat for neuropathic pain assay) were used. They were raised in the International Centre for Chemical and Biological Sciences (ICCBS), University of Karachi, Pakistan under natural conditions $\left(21 \pm 2{ }^{\circ} \mathrm{C}\right.$ temperature, $12 \mathrm{~h} / 12 \mathrm{~h}$ cycle) with access to food and water. The experiments were conducted in agreement with the Institutional Committee for the Use, Care and Standards of Animals (IACUC) of ICCBS following protocol $n^{\circ} 1209004$, accepted by the committee of ethics of ICCBS (Mbiantcha et al. 2017).

\section{Experimental design}


In the acute pain assays, 18 adults' mice were used for each method. They were partitioned into 3 groups of 6 animals each and treated as follows:

- A negative control group (Vehicle), receiving DMSO 2.5\%, p.o;;

- A positive control group (Indo), receiving Indomethacin (10 mg/kg, p.o.);

- A test group (Scyp A), receiving Scyphocephalione A, $50 \mathrm{mg} / \mathrm{kg}$, p.o.).

For the neuropathic pain assays, 24 adult rats were used. There were distributed in 4 groups of 6 animals each and processed as follows:

- A neutral control group (Normal control), without Vincristine sulphate administration;

- A negative control group (Vincristine), receiving Vincristine sulphate $(100 \mu \mathrm{g} / \mathrm{kg}$, i.p.) + vehicle $(2.5 \%$ DMSO, p.o.);

- A positive control group (Morphine), receiving Morphine (10 mg/kg, p.o.) + Vincristine sulphate (100 $\mu \mathrm{g} / \mathrm{kg}$, i.p.);

- A test group (Scyp A), receiving Scyphocephalione A (50 mg/kg, p.o.) + Vincristine sulphate (100 $\mu \mathrm{g} / \mathrm{kg}$, i.p.).

For both in vivo assays the volume of administration was $10 \mathrm{ml} / \mathrm{kg}$. The experiment was carried out for 15 days. On the $15^{\text {th }}$ day after the last test, all the animals were anesthetized by injection of thiopental (50 $\mathrm{mg} / \mathrm{kg}$, i.p.), then the rib cage of each rat was carefully opened and the blood was drawn by catheterization of the abdominal artery and introduced into a $1^{\text {st }}$ tube containing EDTA for the determination of the haematological parameters, then into a second tube without EDTA for the determination of biochemical parameters.

\section{Acute pain}

\section{Acetic acid-induced acute pain assay}

The test was performed by administrating to each mouse $10 \mathrm{ml} / \mathrm{kg}$ (i.p) of acetic acid, $1 \mathrm{~h}$ after the different treatments. Then, mice were placed in sets of two in a glass cage. Five minutes after, the number of writhing (stretching) was recorded for a period of 30 min (Vogel, and Vogel 1997). The percentage of inhibition (\% I) was determined according to the formula below:

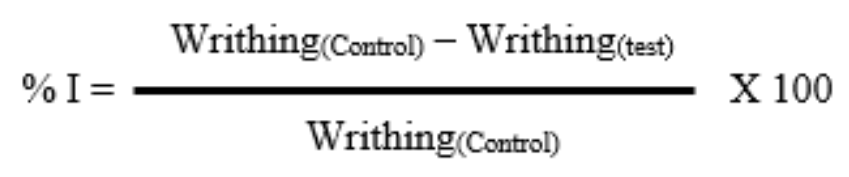

\section{Formalin-induced acute pain assay}

The test was conducted as follow: $1 \mathrm{~h}$ after administration of the different substances, each mouse received an intra-plantar injection of $2.5 \%$ formalin $(100 \mu l)$, then each animal was individually placed in 
a glass cage. The paw licking time (pain materialization) was determined using a chronometer between 0 and 5 min (neurogenic pain), then between 15 and 30 min (inflammatory pain) (Gaertner et al. 1999). The percentage of inhibition (\% I) was determined according to the formula below:

$$
\% \mathrm{I}=\frac{\text { Licking time(Control) }- \text { Licking time (Test) }}{\text { Licking time(Control) }} \times 100
$$

\section{Neuropathic pain}

\section{Vincristine-induced neuropathic pain assay}

The experiment was conducted following the method described by Chiba et al. (2017). Briefly, apart from the animals of the normal control group, all the other rats received Vincristine sulphate $(100 \mu \mathrm{g} / \mathrm{kg}$, i.p.) in two series to induce neuropathic pain: from the $1^{\text {st }}$ to the $5^{\text {th }}$ day, then from the $8^{\text {th }}$ to the $12^{\text {th }}$ day. The treatments with Scyphocephalione A and Morphine were performed one day before induction and continued daily until day 15 .

\section{Behavioral assessment of neuropathic pain}

To assess the effect of Scyphocephalione A on neuropathic pain, mechanical hyperalgesia thermal hyperalgesia and cold allodynia trials were used.

For the mechanical hyperalgesia trial, the hind paw of the rat, placed in a pressure applicator, was stimulated by increasing pressure (cut-off of $250 \mathrm{~g}$ ) until paw withdrawal. The nociceptive threshold value was considered as the force (g) obtained (Hajimashhadi et al. 2017) and was evaluated on days 0 , $1,3,5,7,9,11,13$ and 15 . The percentage (\%) of pain sensitivity latency was determined.

In the thermal hyperalgesia trial, animals were gently placed over the heating plate $\left(50 \pm 0.5^{\circ} \mathrm{C}\right)$, the paw withdrawal latency was recorded in seconds and a cut-off latency of 20 seconds has also been observed (Bhardwaj et al. 2016). The paw withdrawal latency was evaluated on days $0,1,3,5,7,9,11,13$ and 15 . The percentage (\%) of paw withdrawal latency was determined.

Regarding the cold allodynia trial, the tail of each animal was soaked in cold water $\left(4^{\circ} \mathrm{C}\right)$, the time of inactivity of an animal to withdraw its tail was determined with a cut-off of 20 seconds in case of lack of reaction (Mbiantcha et al. 2017). The tail withdrawal latency was evaluated on days $0,2,4,6,8,10,12,14$ and 15 . The percentage (\%) of tail withdrawal latency was determined.

\section{Haematological and Biochemical estimates}

Blood collected into tube containing EDTA was used to evaluate haematological parameter such as haemoglobin, red blood cell (RBC), white blood cell (WBC) and Platelet count. Blood collected into tubes without EDTA was centrifuged at $4900 \mathrm{rpm}$ ( $5 \mathrm{~min}$ ), then the serum was taken for the assay of alanine 
aminotransferase (ALT), alkaline phosphatase (ALP), aspartate aminotransferase (AST), creatinine (Bhardwaj et al. 2016; Mbiantcha et al. 2017), glutathione (GSH) (Ellman 1959), catalase (Sinha 1972), superoxide dismutase (SOD) (Misra, and Fridovich 1972), NO and malondialdehyde (MDA) (Wilbur et al. 1949).

\section{Statistical analysis}

For in vitro assays, samples were ran out in triplicate and the results were presented as percentage inhibition; while for the in vivo assays, the results were analyzed by one-way ANOVA followed by Tukey or Bonferroni post-tests. Data were expressed as mean \pm SEM. A p-value $<0.05$ was considered significant (GraphPad Prism, version 5.03).

\section{Results}

\section{In vitro anti-inflammatory activities of Scyphocephalione A}

Table 1 shows the effects of Scyphocephalione A on proteins denaturation, cyclooxygenase and 5lipoxygenase activities. It emerges from this table that Scyphocephalione A inhibits proteins denaturation as well as cyclooxygenase and 5-lipoxygenase activities. This inhibition is concentration-dependent as well as Diclofenac and Ibuprofen. At a concentration of $1000 \mu \mathrm{g} / \mathrm{ml}$, Scyphocephalione A inhibits protein denaturation, cyclooxygenase and 5-lipoxygenase activities with percentages of $74.21 \%, 75.80 \%$ and $64.43 \%$ respectively. Furthermore, at the same concentration diclofenac inhibited proteins denaturation by $85.10 \%$, while ibuprofen inhibits cyclooxygenase and 5 -lipoxygenase activities by $95.24 \%$ and $96.19 \%$ respectively. 
Table 1

Effect of Scyphocephalione A on proteins denaturation, cyclooxygenase and 5-lipoxygenase inhibitions

\begin{tabular}{|c|c|c|c|c|}
\hline \multirow[t]{2}{*}{ Compounds } & \multirow[t]{2}{*}{ Dose $(\mu \mathrm{g} / \mathrm{ml})$} & \multicolumn{3}{|l|}{ Inhibition (\%) } \\
\hline & & Proteins denaturation & Cyclooxygénase & 5-lipoxygénase \\
\hline \multirow[t]{4}{*}{ Diclofenac } & 100 & 63.33 & - & - \\
\hline & 200 & 71.25 & - & - \\
\hline & 500 & 80.21 & - & - \\
\hline & 1000 & 85.10 & - & - \\
\hline \multirow[t]{4}{*}{ Ibuprofen } & 100 & - & 80.44 & 77.02 \\
\hline & 200 & - & 83.09 & 82.30 \\
\hline & 500 & - & 89.11 & 90.43 \\
\hline & 1000 & - & 95.24 & 96.19 \\
\hline \multirow[t]{4}{*}{ Scyphocephalione A } & 100 & 55.32 & 45.10 & 40.21 \\
\hline & 200 & 60.66 & 49.55 & 44.50 \\
\hline & 500 & 67.43 & 62.32 & 55.50 \\
\hline & 1000 & 74.21 & 75.80 & 64.43 \\
\hline
\end{tabular}

In vivo antinociceptive activities of Scyphocephalione A

Figures 2 and 3 show the analgesic effects of Scyphocephalione A on acute pain models induced by acetic acid and formalin respectively. It was found that the injection of acetic acid induced $103.00 \pm 3.99$ writhing (abdominal contortions) in animals of the negative control group. This number of writhing was significantly $(p<0.001)$ reduced by $35.76 \%$ ( $66.17 \pm 1.76$ writhing) in animals treated with indomethacin and by $63.43 \%$ (37.67 \pm 2.87 writhing) in animals treated with Scyphocephalione A (Figure 2). Regarding the two phases of formalin-induced pain, compared to Vehicle, Scyphocephalione A induced a significant $(p<0.001)$ decrease of linking time. The inhibition of linking time was observed in the first and second phase (42.12\% and $67.53 \%$ inhibition respectively). Indomethacin inhibited the linking time in the first $(8.61 \%)$ and second phase $(28.32 \%, p<0.001)$ in comparison to the Vehicle (Figure 3$)$.

\section{Effects of Scyphocephalione A on some behavioral parameters of rat submitted to Vincristine-induced neuropathic pain}


Figure 4 shows the effects of Scyphocephalione A on mechanical hyperalgesia (Figure 4A), thermal hyperalgesia (Figure 4B) and cold allodynia (Figure 4C) induced by analgesimeter, hotplate and cold water respectively. It emerges from these results that, compared to Normal control group, after injection of Vincristine, the animals of Vehicle group progressively develop an increase in sensitivity to pain reflecting the installation of peripheral neuropathy. This hypersensitivity, marked by a decrease in percentage (\%) of pain sensitivity latency (Figure 4A), percentage (\%) of paw withdrawal latency (Figure 4B) and percentage $(\%)$ of tail withdrawal latency (Figure $4 C$ ), was significant $(p<0.001)$ from the third to the fifteenth day post induction. Oral administration of Scyphocephalione A, as well as Morphine, protected animals against hypersensitivity by increasing the percentage (\%) of pain sensitivity latency (Figure 4A), percentage (\%) of paw withdrawal latency (Figure 4B) and percentage (\%) tail withdrawal latency (Figure 4C). For all behavioural parameters studied, the effect of Scyphocephalione A was significant $(p<0.05$; $p<0.01 ; p<0.001$ ) from day 3 until day 15 , compared to the Vehicle group.

\section{Effects of Scyphocephalione A on some haematological and biochemical parameters of rat submitted to Vincristine-induced neuropathic pain}

As shown in Table 2, compared to animals of the Normal control group, those in the Vehicle group which received only Vincristine showed a significant decrease $(p<0.01 ; p<0.001)$ in all the evaluated haematological parameters (haemoglobin, RBC, WBC levels; haematocrit percentage and platelet count). The treatment with Scyphocephalione A, as well as Morphine, prevented the effects induced by Vincristine. All the haematological parameters of Scyphocephalione A group were similar to the values of the animals of the Normal control group (Table 2).

Table 2: Effects of Scyphocephalione A on blood parameters of rat submitted to Vincristine-induced neuropathic pain 


\begin{tabular}{|c|c|c|c|c|c|c|}
\hline & $\begin{array}{l}\text { Dose } \\
(\mathrm{mg} / \mathrm{kg})\end{array}$ & $\begin{array}{l}\text { Haemoglobin } \\
(\mathrm{g} / \mathrm{dl})\end{array}$ & $\begin{array}{l}\text { RBC } \\
\text { (million/ } \mu \mathrm{l})\end{array}$ & $\begin{array}{l}\text { Hematocrit } \\
\text { (\%) }\end{array}$ & $\begin{array}{l}\text { WBC } \\
\left(10^{9} / \mathrm{L}\right)\end{array}$ & $\begin{array}{l}\text { Platelet } \\
\text { count } \\
\left(10^{9} / \mathrm{L}\right)\end{array}$ \\
\hline Normal control & - & $\begin{array}{l}12.45 \pm \\
0.25\end{array}$ & $\begin{array}{l}7.06 \pm \\
0.19\end{array}$ & $\begin{array}{l}40.38 \pm \\
1.11\end{array}$ & $\begin{array}{l}7.58 \pm \\
0.28\end{array}$ & $\begin{array}{l}831.75 \\
\pm \\
34.48\end{array}$ \\
\hline Vehicle & - & $\begin{array}{l}7.15 \pm \\
0.39 y\end{array}$ & $\begin{array}{l}3.90 \pm \\
0.19^{Y}\end{array}$ & $\begin{array}{l}25.93 \pm \\
1.03^{Y}\end{array}$ & $\begin{array}{l}1.68 \pm \\
0.14^{\beta}\end{array}$ & $\begin{array}{l}481.25 \\
\pm \\
26.80^{\beta}\end{array}$ \\
\hline Morphine & 5 & $\begin{array}{l}11.60 \pm \\
0.35^{\mathrm{c}}\end{array}$ & $\begin{array}{l}6.05 \pm \\
0.52^{\mathrm{ac}}\end{array}$ & $\begin{array}{l}35.10 \pm \\
1.27^{b}\end{array}$ & $\begin{array}{l}9.00 \pm \\
0.52^{c}\end{array}$ & $\begin{array}{l}1074.00 \\
\pm \\
15.01^{\beta c}\end{array}$ \\
\hline $\begin{array}{l}\text { Scyphocephalione } \\
\text { A }\end{array}$ & 50 & $\begin{array}{l}12.15 \pm \\
0.28^{\mathrm{c}}\end{array}$ & $\begin{array}{l}6.68 \pm \\
0.10^{c}\end{array}$ & $\begin{array}{l}38.63 \pm \\
0.74^{c}\end{array}$ & $\begin{array}{l}6.48 \pm \\
1.13^{b}\end{array}$ & $\begin{array}{l}1137.00 \\
\pm \\
54.60^{\beta C}\end{array}$ \\
\hline
\end{tabular}

Each value represents the mean \pm E.S.M., $n=6 .{ }^{\beta} p<0.01,{ }^{Y_{p}}<0.001$ vs. Normal control; ${ }^{b} p<0.01 ;{ }^{c} p<0.001$ vs. Vehicle (one-way ANOVA followed by Tukey's post-test). RBC: red blood cell; WBC: white blood cell.

The Table 3 summarizes the values of some serum parameters of oxidative stress biomarkers evaluated at the end of treatment. According to the Table, the injection of vincristine in animals (Vehicle group) caused a significant increase $(p<0.001)$ of NO and MDA levels; and a significant decrease $(p<0.001)$ of catalase, glutathione levels and superoxide dismutase activity, compared to the Normal control group. The treatment of animals with Scyphocephalione A induced a significant decrease in NO $(p<0.001)$ and MDA $(p<0.01)$ levels; and a significant $(p<0.001)$ increase in glutathione levels as well as catalase and superoxide dismutase activities (Table 3 ). 
Table 3

Effect of Scyphocephalione A on some parameters of oxidative stress of rat submitted to Vincristineinduced neuropathic pain.

\begin{tabular}{|c|c|c|c|c|c|c|}
\hline Treatment & Dose (mg/kg) & $\begin{array}{l}\text { NO } \\
(\mu \mathrm{mol})\end{array}$ & $\begin{array}{l}\text { MDA } \\
\left(\times 10^{6} \mu \mathrm{mol} / \mathrm{l}\right)\end{array}$ & $\begin{array}{l}\text { CAT } \\
\text { (IU) }\end{array}$ & $\begin{array}{l}\text { GSH } \\
\left(\times 10^{5} \mathrm{IU}\right)\end{array}$ & $\begin{array}{l}\text { SOD } \\
\text { (IU) }\end{array}$ \\
\hline \multirow[t]{2}{*}{ Normal control } & I & $0.067 \pm$ & $5.30 \pm$ & $71.22 \pm$ & $5.44 \pm$ & $2.30 \pm$ \\
\hline & & 0.002 & 0.94 & 1.41 & 0.13 & 0.10 \\
\hline \multirow[t]{2}{*}{ Vehicle } & / & $0.099 \pm$ & $11.00 \pm$ & $31.39 \pm$ & $2.29 \pm$ & $1.30 \pm$ \\
\hline & & $0.003^{Y}$ & $1.03^{Y}$ & $1.03^{Y}$ & $0.21^{Y}$ & $0.02^{Y}$ \\
\hline \multirow[t]{2}{*}{ Morphine } & 5 & $0.076 \pm$ & $8.30 \pm$ & $57.99 \pm$ & $4.53 \pm$ & $1.91 \pm$ \\
\hline & & $0.001^{a c}$ & $0.17^{a}$ & $1.10^{\mathrm{Yc}}$ & $0.11^{\beta c}$ & $0.05^{b}$ \\
\hline \multirow[t]{2}{*}{ Scyphocephalione A } & 50 & $0.061 \pm$ & $6.52 \pm$ & $69.06 \pm$ & $5.30 \pm$ & $2.20 \pm$ \\
\hline & & $0.002^{c}$ & $0.16^{\mathrm{b}}$ & $1.60^{c}$ & $0.22^{c}$ & $0.19^{c}$ \\
\hline $\begin{array}{l}\text { Each value represent } \\
b_{p}<0.01, c_{p}<0.001 \text { vs. } \\
\text { Malondialdehyde; CA }\end{array}$ & $\begin{array}{l}\text { e mean } \pm \text { E.S.N } \\
\text { hicle (one-way }\end{array}$ & $\begin{array}{l}n=6 .{ }^{a} p \\
\text { NOVA foll } \\
\text { utathione }\end{array}$ & $\begin{array}{l}.05,{ }^{\beta} p<0.01,{ }^{p} p \\
\text { ved by Tukey's }\end{array}$ & $\begin{array}{l}001 \text { vs. ^ } \\
\text { st-test). ^ } \\
\text { lismutas }\end{array}$ & $\begin{array}{l}\text { rmal contro } \\
\text { : nitric oxid }\end{array}$ & MDA: \\
\hline
\end{tabular}

As shown in Table 4, the injection of Vincristine (Vehicle group) caused significant $(p<0.001)$ increases in ALT, AST, ALP and creatinine levels, compared to the Normal control group. Also, compared to the Vehicle group, the treatment with Scyphocephalione $A$, as well as Morphine, induced a significant $(p<0,001)$ decrease in all the serum parameters evaluated in this study (Table 4). 
Table 4

Effect of Scyphocephalione A on serum parameters of rat submitted to Vincristine-induced neuropathic pain.

\begin{tabular}{|c|c|c|c|c|c|}
\hline & $\begin{array}{l}\text { Dose } \\
\text { (mg/kg) }\end{array}$ & $\begin{array}{l}\text { ALP } \\
(U / I)\end{array}$ & $\begin{array}{l}\text { AST } \\
(\mathrm{U} / \mathrm{I})\end{array}$ & $\begin{array}{l}\text { ALT } \\
(\mathrm{U} / \mathrm{I})\end{array}$ & $\begin{array}{l}\text { Creatinine } \\
\text { (mg/dl) }\end{array}$ \\
\hline Normal control & - & $72.80 \pm 1.83$ & $41.20 \pm 2.56$ & $44.00 \pm 2.03$ & $0.41 \pm 0.03$ \\
\hline Vehicle & - & $481.00 \pm 9.68^{Y}$ & $\begin{array}{l}182.00 \pm \\
7.23^{Y}\end{array}$ & $\begin{array}{l}136.00 \pm \\
3.03^{Y}\end{array}$ & $\begin{array}{l}0.87 \pm \\
0.01^{Y}\end{array}$ \\
\hline Morphine & 5 & $\begin{array}{l}186.00 \pm \\
27.70^{\text {rc }}\end{array}$ & $\begin{array}{l}85.00 \pm \\
4.18^{\mathrm{Vc}}\end{array}$ & $\begin{array}{l}97.00 \pm \\
3.03^{\gamma c}\end{array}$ & $\begin{array}{l}0.58 \pm \\
0.03^{\mathrm{ac}}\end{array}$ \\
\hline $\begin{array}{l}\text { Scyphocephalione } \\
\text { A }\end{array}$ & 50 & $110.40 \pm 3.19^{c}$ & $\begin{array}{l}53.40 \pm \\
4.77^{c}\end{array}$ & $\begin{array}{l}105.80 \pm \\
1.88^{\mathrm{Vc}}\end{array}$ & $\begin{array}{l}0.43 \pm \\
0.04^{c}\end{array}$ \\
\hline \multicolumn{6}{|c|}{$\begin{array}{l}\text { ALP: alkaline phosphatase; AST: aspartate aminotransferase; ALT: alanine aminotransferase. Each } \\
\text { value represents the mean } \pm \text { ESM for six animals and analysed by two-way ANOVA followed by Tukey } \\
\text { post-hoc test, }{ }^{a} p<0.05 ; \vee \vee P<0.001 \text { when compared to normal control, }{ }^{c} P<0.001 \text { when compared to } \\
\text { vincristine and vehicle. }\end{array}$} \\
\hline
\end{tabular}

\section{Discussion}

The purpose of this study was to evaluate in vitro and in vivo the possible anti-inflammatory activities (by inhibiting the proteins denaturation, cyclooxygenase and 5-lipoxygenase activities), analgesic (by inhibiting acute pain induced by acetic acid and formalin) and antihyperalgesic (by inhibiting neuropathic pain induced by Vincristine) effects of Scyphocephalione A, a dibenzofuran derivative isolated from Scyphocephalium ochocoa (Myristicaceae). The results obtained in this study clearly show that this compound has anti-inflammatory, antioxidant, analgesic and antihyperalgesia properties.

In the evaluation of acute pains, acetic acid and formalin are two solutions commonly used to assess the analgesic properties of new drugs. In fact, it is well known that intraperitoneal injection of acetic acid causes abdominal writhing after activation of mast cells and macrophages, and production of eicosanoids, TNFa, sympathomimetic amines and IL-1 3 (Ribeiro et al. 2000); while the intra-plantar injection of formalin induces a sensation of pain materialized by the licking of the paw which develops in two phases, a first which is characterized by neurogenic pain and a second phase characterized by inflammatory pain. Our results have shown that compared to the vehicle group, Scyphocephalione A, at a dose of $50 \mathrm{mg} / \mathrm{kg}$, induced a significant reduction in the number of abdominal writhing caused by acetic acid. The compound at the same dose, also induced a significant reduction of the paw licking time during both phases of pain induced by formalin. The effects produced by Scyphocephalione A are much greater than those produced by indomethacin used as a reference drug in this study. The presence of acetic acid in the peritoneal cavity causes irritation of the cavity, significant stimulation of nociceptors and then 
production of serotonin, prostaglandins, histamine, substance $P$ and bradykinin (Konaté et al. 2012). Otherwise, the presence of formalin in the plant of the animal's paw causes initially (from 0 to $10 \mathrm{~min}$ ) a production of serotonin and bradykinin, then secondly (from 10 to $30 \mathrm{~min}$ ) a production of prostaglandins, TNF-a, IL-6 and IL-1 $\beta$ (Magro et al. 2013). The effects of Scyphocephalione A on the model of acetic acid-induced pain and on both phases of formalin-induced pain suggests that this compound has the ability to inhibit the production and/or activity of numerous inflammatory mediators and/or endogenous substances responsible for producing the painful sensation. These results also suggest that Scyphocephalione A may have both central and peripheral analgesic activities.

Vincristine is an anti-cancers drug, widely used in oncology. Its clinical use remains limited due to its great affinity with $\beta$-tubulin in the microtubules of the nervous system, resulting in the development of painful neuropathy (Schwartz 2009). As shown by some authors, its injection in rodents for a period of 10 days induce a partial degeneration of the sensory nerves in the form of loss of $A \delta$ and $C$ fibres followed by a significant increase in mechanical, thermal and cold sensitivity, a consequence of the peripheral neuropathy development (Ochoa and Yarnitsky 1994; Latters and Bennett 2004; Siau et al. 2006). Most of the patients suffering from neuropathic pain present numerous clinical signs such as allodynia and hyperalgesia, although the mechanisms underlying their occurrence are not clearly defined. In this study, compared to the Normal control group, injection of vincristine (Vehicle group) resulted in hypersensitivity in all animals characterized by mechanical, thermal and cold hyperalgesia. Compared to Vehicle group, administration of Scyphocephalione $A$ at a dose of $50 \mathrm{mg} / \mathrm{kg}$ significantly reduced this hypersensitivity. In addition, the effect of this compound on behavioural parameters was greater than that of Morphine (5 $\mathrm{mg} / \mathrm{kg}$ ) used as a reference drug. It has been shown that in rodents which develop neuropathic pain, several mononuclear cells are released and they will produce numerous pro-inflammatory molecules such as PGE2 and TNFa. At the level of different cell types, these molecules are able to induce a pro-apoptotic effect, thus maintaining and/or extending the state of hypersensitivity (Mantuano et al. 2011).

It is well known that leukotriene receptor antagonists and/or 5-lipoxygenase inhibitors have significant therapeutic value in the management of neuropathic pain, a fact that is notable in many cases of neuropathic pain. Administration of leukotriene receptor antagonist (Montelukast), active 5-lipoxygenase inhibitor (Zileuton) and/or non-steroidal anti-inflammatory drug (Indomethacin) significantly alleviated clinical symptoms (Singh et al. 2005; Cortes-Burgos et al. 2009). Thus, the combined inhibitors of leukotriene, prostaglandins, and the production of TNFa as well as NO would have advantages in the management of neuropathic pain compared to existing drugs. In this study, in vitro tests showed that Scyphocephalione A, as well as Diclofenac an Ibuprofen, inhibited in a concentration dependent manner proteins denaturation of and the activities of cyclooxygenase and 5-lipoxygenase. Previous work performs by Feuya Tchouya et al. (2021) have shown that Scyphocephalione A has inhibitory properties on the production of TNFa and NO. All these results suggest that the analgesic and antihyperalgesic effects of Scyphocephalione A are linked to its ability to inhibit the production of PGE2 (marked by inhibition of cyclooxygenase), leukotrienes (marked by inhibition of 5-lipoxygenase), TNFa and NO. 
Painful neuropathy accompanying tissue damage can be maintained by an increase in the production of free radicals (Muthuraman et al. 2008; Park et al. 2010). It is well known that in many models of neuropathic pain induced by anticancer drugs, the high production of free radicals leads the induction of neuronal cytotoxicity, thus causing the development of painful neuropathy (Wang et al. 2000; Joseph et al. 2008; Muthuraman et al. 2011). In this study, compared to the Normal control group, animals having received only Vincristine showed a significant increase in pro-oxidant substances (MDA, NO) and a significant decrease in anti-oxidants (catalase, glutathione, superoxide dismutase). These effects induce by Vincristine reflect a significant state of oxidative stress in these animals. However, animals which received Scyphocephalione A showed a significant reduction of this state of stress, compared to the vehicle-treated group. This was marked by a significant decrease in the levels of MDA and NO, and a significant increasing in the glutathione level as well as catalase and superoxide dismutase activities.

Many anticancer treatments seriously affect liver function and haematological function by inducing a significant increase in the activities of ALT, ALP, AST as well as a significant decrease in the blood components (white blood cells, red blood cells, haematocrit percentage and platelets) (Harrison Jr 1983; Siau et al. 2006). The results obtained in this study showed that compared to the Normal control group, injection of vincristine (Vehicle group) induced a significant decrease in serum levels of white blood cells, red blood cells, haematocrit and platelets, followed by an increase in serum activities of ALT, ALP and AST. These findings are in agreement with the results obtained in our previous work (Mbiantcha et al. 2017; Mbiantcha et al. 2018), as well as those obtained by Lahouel et al. (1987) and Raguenez-Viotte et al. (1988). These results are justified by the fact that the injection of Vincristine in animals causes severe liver damage and seriously affects haematopoiesis through its action on the bone marrow (Hansen et al. 1982; Nag and Katherine 1984). Compared to the Vehicle group, treatment of animals with Scyphocephalione A significantly improved parameters of hepatic and hematologic parameters that were altered following Vincristine administration. This was marked by a decrease in liver enzymes (ALT, ALP and AST) activities and an increase in blood components (white blood cells, red blood cells, haematocrit and platelets) levels. The hepatoprotective and/or immune function regulatory effects of Scyphocephalione A could be associated with its antioxidant and/or anti-inflammatory properties.

\section{Conclusion}

The anti-inflammatory properties in vitro, followed by the in vivo analgesic and antihyperalgesic properties of Scyphocephalione A, were demonstrated in this study. Scyphocephalione A also induced a significant reduction of the observed side effects after Vincristine injection. The results of this study suggest that Scyphocephalione $A$ is able to prevent the development of painful neuropathy and to reduce the hepatic and haematological adverse effects associated with vincristine administration in the treatment of cancers. This demonstrates that Scyphocephalione A is a promising molecule for the management of peripheral neuropathic pain induced by anti-cancer drugs.

\section{Abbreviations}


TRPM8: Transient receptor potential cation channel subfamily M (melastatin) member 8

TRPA1: transient receptor potential ankyrin subtype 1 protein

MCF-7 cell line: Mammary carcinoma cell lines

DCM : dichloromethane

$\mathrm{MeOH}$ : methanol

RPMI 1640: Roswell Park Memorial Institute medium

TCA : Tricloro acetic acid

$\mathrm{HCl}$ : Chlorhydrique acid

TBA: thiobarbituric acid

OD : optical density

ICCBS: International Centre for Chemical and Biological Sciences

DMSO: Dimethyl sulphoxide

EDTA: Ethylene Diamine Tetra-acetique acid

RBC: red blood cell

WBC: white blood cell

ALT: alanine aminotransferase

ALP: alkaline phosphatase

AST: aspartate aminotransferase

GSH: glutathione

SOD: superoxide dismutase

NO : Nitrite oxide

MDA: malondialdehyde

ANOVA: One-way analysis of variance

TNFa : Tumor necrosis factor alpha 
IL : Interleukin

\section{Declarations}

\section{Data availability}

The datasets used during the current study are available from the corresponding author on reasonable request.

\section{Conflicts of Interest}

The authors declare that they have no conflicts of interest.

\section{Acknowledgments}

The authors would like to thank the study participants and the staff of diagnostic Laboratory of Dr. Panjwani Center for Molecular Medicine and Drug Research, University of Karachi, Pakistan, for the biochemical analysis. The authors wish to express their profound heartfelt gratitude to TWAS (Academy of Science of Developing Countries), ICCBS (International Center for Chemical and Biological Sciences, University of Karachi), and Dr. Panjwani Center for Molecular Medicine and Drug Research (University of Karachi) for the fellowship awarded that allowed carrying the enclosed described work and to exchange between Cameroonian and Pakistani researchers.

\section{Ethical Approval}

All these animals, reared under natural conditions $\left(21 \pm 2{ }^{\circ} \mathrm{C}\right.$ temperature, $12 \mathrm{~h} / 12 \mathrm{~h}$ cycle) with access to food and water, came from the International Center for Chemical and Biological Sciences ((ICCBS), University of Karachi, Pakistan). The treatment of animals as well as the number used in each group were in agreement with the Institutional Committee for the Use, Care and Standards of Animals (IACUC) of ICCBS following protocol $n^{\circ} 1209004$, accepted by the committee of ethics of ICCBS (University of Karachi, Pakistan)

\section{Authors' Contributions}

Mbiantcha Marius, Feuya Tchouya Guy Raymond and Yousseu Nana William contributed to writing the paper and study designs. Mbiantcha Marius, Atsamo Albert Donatien and Foundikou Hibrahim contributed to the analysis and interpretation of data. Supervision of study and review of the paper were done by Foundikou Hibrahim, Lebibi Jacques and Zemo Gamo Franklin. All authors have read and approved the final version of the manuscript.

\section{References}

1. Airiau C (1999) Drug-induced neuropathies: review. J de Pharm Clin 18 : 90-94. 
2. Authier N, Gillet JP, Fialip J, Eschalier A, Coudore F (2003) A New Animal Model of Vincristine-Induced Nociceptive Peripheral Neuropathy. NeuroToxicology 24:797-805.

3. Besson JM (1999) The neurobiology of pain. Lancet 353: 1610-1615.

4. Bhardwaj HC, Muthuraman A, Hari KSL, Navis S (2016) Antioxidative and anti-inflammatory potentials of ambroxol in ameliorating vincristine induced peripheral neuropathic pain in rats. Journal of Neuroinfectious Diseases 7: 202, doi:10.4172/2314-7326.1000202.

5. Boyle FM, Wheeler HR, Shenfield GM (1996) Glutamate ameliorates experimental vincristine neuropathy. J Pharmacol Exp Ther 279: 410-415.

6. Chiba T, Oka Y, Sashida H, Kanbe T, Abe K, Utsunomiya I et al (2017) Vincristine-induced peripheral neuropathic pain and expression of transient receptor potential vanilloid 1 in rat. J Pharmacol Sci 133:254-260.

7. Cortes-Burgos LA, Zweifel BS, Settle SL, Pufah RAl, Anderson GD, Hardy MM, Weir DE, Hu G, Happa FA, Stewart Z, Muthian S, Graneto MJ, Masferrer JL (2009) CJ-13610, an orally active inhibitor of 5lipoxygenase is efficacious in preclinical models of pain. Eur. J. Pharmacol 617:59-67.

8. Davis JL, Lewis SB, Gerich JE, Kaplan RA, Schultz TA, Wallin JD (1977) Peripheral diabetic neuropathy treated with amitriptyline and fluphenazine. JAMA 238: 2291-2292.

9. Djuichou Nguemnang SF, Tsafack EG, Mbiantcha M et al (2019) In vitro anti-inflammatory and in vivo antiarthritic activities of aqueous and ethanolic extracts of Dissotis thollonii Cogn.

(Melastomataceae) in rats. Evid Based Complement Alternat Med 2019, Article ID 3612481: 17.

10. Doyle JA, Manchester SR, Sauquet H (2008) A seed related to Myristicaceae in the Early Eocene of southern England. Syst Bot 33(4): 636-646.

11. Dworkin RH, O’Connor AB, Audette J, Baron R, Gourlay GK, Haanpaa ML et al (2010) Recommendations for the pharmacological management of neuropathic pain: an overview and literature update. Mayo Clin Proc 85(Suppl):S3-14.

12. Ellman GL (1959) Tissue sulfhydryl groups. Arch Biochem Biophys 82(1): 70-77.

13. Feuya Tchouya GR, Foundikou H, Mbiantcha M, Bankeu Kezetas JJ, Bongui JB, Tchouankeu JC, Lebibi J, Dethe DH (2021) A new dibenzofuran derivative from the stem bark of Scyphocephalium ochocoa with anti-inflammatory and cytotoxic activities. Nat Prod Res 2021: DOI:

10.1080/14786419.2021.1894561.

14. Feuya Tchouya GR, Souza A, Tchouankeu JC, Yala JF, Boukandou M, Foundikou H, Nguema Obiang GD, Fekam-Boyom F, Mabika-Mabika R et al (2015) Ethnopharmacological surveys and pharmacological studies of plants used in traditional medicine in the treatment of HIV/AIDS opportunistic diseases in Gabon. J Ethnopharmacol 162: 306-316.

15. Foundikou H, Mbiantcha M, Bankeu JJK, Tchouankeu JC, Shaheen F, Choudhary MI, Lebibi J, Feuya Tchouya GR (2018) Two new alkylresorcinol derivatives from the leaves of Scyphocephalium ochocoa. Z Naturforsch B 73(6): 381-388.

16. Freitas MA, Vasconcelos A, Gonçalves ECD, Ferrarini EG, Vieira GB, Cicia D, Cola M, Capasso R, Dutra RC (2021) Involvement of Opioid System and TRPM8/TRPA1 Channels in the Antinociceptive Effect 
of <i>Spirulina platensis</i>. Biomolecules 11(4):592.

17. Gaertner M, Müller L, Roos JF, Cani G, Santos ARS, Neiro R, Calixto JG, Yuner RA, Delle Monache F, Cechenel-Filho V (1999) Analgesic triterpenes from Sebastiania schottiana roots. Phytomedicine 6:41-44.

18. Gidding CEM, Kellie SJ, Kamps WA, De Graaf SSN (1999) Vincristine revisited. Crit Rev Oncol Hematol 29(3):267-287.

19. Gomber S, Dewan P, Chhonker D (2010) Vincristine induced neurotoxicity in cancer patients. Indian J Pediatr 77: 97-100.

20. Gonçalves ECD, Baldasso GM, Bicca MA, Paes RS, Capasso R, Dutra RC (2020) Terpenoids, Cannabimimetic Ligands, beyond the <i>Cannabis</i> Plant. Molecules 25(7): 1567.

21. Goni O, Khan MF, Rahman MM, Hasan MZ, Kader FB, Sazzad N, Sakib MA, Romano B, Haque MA, Capasso R (2021) Pharmacological insights on the antidepressant, anxiolytic and aphrodisiac potentials of Aglaonema hookerianum Schott. J Ethnopharmacol 268: 113664.

22. Hajimashhadi Z, Aboutaleb N, Nasirinezhad F (2017) Chronic administration of [Pyr1] apelin-13 attenuates neuropathic pain after compression spinal cord injury in rats. Neuropeptides 61: 15-22.

23. Han Y, Smith MT (2013) Pathobiology of cancer chemotherapy induced peripheral neuropathy (CIPN). Front Pharmacol 4:156.

24. Hansen MM, Ranek L, Walbom S, Nissen NI (1982) Fatal hepatitis following irradiation and vincristine. J. Intern. Med 212(3): 171-174.

25. Harrison Jr SD (1983) An investigation of the mouse as a model for vincristine toxicity. Cancer Chemother. Pharmacol 11(1): 62-65.

26. Hewitt DJ, McDonald M, Portenoy RK, Rosenfeld B, Passik S, Breitbart W (1997) Pain syndromes and aetiologies in ambulatory AIDS patients. Pain 70:117-123.

27. Joseph EK, Chen X, Bogen O, Levine JD (2008) Oxaliplatin acts on IB4-positive nociceptors to induce an oxidative stress-dependent acute painful peripheral neuropathy. J Pain 9: 463-472.

28. Joseph EK, Levine JD (2009) Comparison of oxaliplatin- and cisplatin-induced painful peripheral neuropathy in the rat. $J$ Pain 10: 534-541.

29. Kahng J, Kim TK, Chung EY, Kim YS, Moon JY (2015) The effect of thioctic acid on allodynia in a rat vincristine induced neuropathy model. $J$ Int Med Res 43(3):350-355.

30. Kehlet $\mathrm{H}$, Jensen TS, Woolf CJ (2006) Persistent postsurgical pain: risk factors and prevention. Lancet 367:1618-1625.

31. Konaté K, Bassolé IHN, Hilou A, Aworet Samseny RR, Souza A, Barro N, Dicko MH, Datté JY, M'Batchi $B$ (2012) Toxicity assessment and analgesic activity investigation of aqueous acetone extracts of Sida acuta Burn f. and Sida cordifolia L. (Malvaceae), medicinal plants of Burkina Faso. BMC Complement Altern Med 2012, doi:10.1186/1472-6882-12-120.

32. Kumar G, Soni CR (2009) Central post-stroke pain: current evidence. J Neurol Sci 284: 10-17. 
33. Küpeli Akkol E, Genç Y, Karpuz B, Sobarzo-Sánchez E, Capasso R (2020) Coumarins and CoumarinRelated Compounds in Pharmacotherapy of Cancer. Cancers (Basel) 12(7): 1959.

34. Lahouel M, Viotte G, Sumereau, Morin JP, Fillastre JP (1987) Haematotoxicity of doxorubicin and CCNU and of their association in rats. Drugs Exp Clin Res 13(10): 593-599.

35. Latters SJ, Bennett GJ (2004) Ethosuximide reverses paclitaxel and vincristine-induced painful peripheral neuropathy. Pain 109: 150-161.

36. Magro D, Hohmann M, Mizokami S, Cunha T, Alves-Filho J, Casagrande R, Ferreira S, Liew F, Cunha F, Verri WJ (2013) An interleukin-33/ST2 signaling deficiency reduces overt pain-like behaviors in mice. Braz. J. Med. Biol. Res 46: 601-606.

37. Mantuano E, Henry K, Yamauchi T, Hiramatsu N, Yamauchi K, Orita S, Takahashi K, Lin JH, Gonias SL, Campana WM (2011) The unfolded protein response is a major mechanism by which LRP1 regulates Schwann cell survival after injury. J. Neurosci 31: 13376-13385.

38. Martínez V, Iriondo De-Hond A, Borrelli F, Capasso R, Del Castillo MD, Abalo R (2020) Cannabidiol and Other Non-Psychoactive Cannabinoids for Prevention and Treatment of Gastrointestinal Disorders: Useful Nutraceuticals?. Int J Mol Sci 21(9):3067.

39. Mbiantcha M, Almas J, Ateufack G, Shabana US, Bomba Tatsinkou FD, Nida D (2018) NO-cGMP-K channel-dependent anti-nociceptive activities of methanol stem bark extract of Piptadeniastrum africanum (Mimosaceae) on rats. Asian Pac J Trop Biomed 8(3):150-159.

40. Mbiantcha M, Dawe A, Atsamo AD, Ateufack G, Yousseu Nana W, Khalid R, Mehreen A, Fanta Yadang SA, Njoku IS, Hamza D, Naeem UR, Izhar A (2020) In Vitro Antioxidant, Anti-inflammatory, and In Vivo Anticolitis Effects of Combretin A and Combretin B on Dextran Sodium Sulfate-Induced Ulcerative Colitis in Mice. Gastroenterol Res Pract 2020, Article ID 4253174:12, https://doi.org/10.1155/ 2020/4253174.

41. Mbiantcha M, Ngouonpe WA, Dawe A, Yousseu NW, Ateufack G (2017) Antinociceptive activities of the methanolic extract of the stem bark of Boswellia dalzielii Hutch. (Burseraceae) in rats are NO/cGMP/ATP Sensitive- $\mathrm{K}^{+}$channel activation dependent. Evid Based Complement Alternat Med 2017: 12, doi: https://doi.org/10.1155/2017/6374907.

42. Mehta A, Sethiya N, Mehta C, Shah G (2012) Anti-arthritis activity of roots of Hemidesmus indicus R. Br. (Anantmul) in rats. Asian Pac. j. trop. med 5(2): 130-135.

43. Misra HP, Fridovich I (1972) The role of superoxide anion in the autooxidation of epinephrine and a simple assay for superoxide dismutase. J. Biol. Chem 247:3170-3175.

44. Mori F, Codeca C, Kusayanagi H, Monteleone F, Buttari F, Fiore S et al (2010) Effects of anodal transcranial direct current stimulation on chronic neuropathic pain in patients with multiple sclerosis. J Pain 11: 436-442.

45. Muthuraman A, Jaggi AS, Singh N, Singh D (2008) Ameliorative effects of amiloride and pralidoxime in chronic constriction injury and vincristine-induced painful neuropathy in rats," Eur J Pharmacol 587: 104-111. 
46. Muthuraman A, Singh N, Jaggi AS (2011) Protective effect of Acorus calamus L. in rat model of vincristine induced painful neuropathy: an evidence of anti-inflammatory and anti-oxidative activity. Food Chem. Toxicol 49:2557-2563.

47. Nag SES, Katherine AH (1984) Hepatotoxicity Following Vincristine Terapy. Cancer 54(9):2006-2008.

48. Ngoua-Meye-Misso RL, Sima-Obiang C, Ndong JDLC, Ndong-Atome GR, Ondo JP, Abessolo FO, Obame-Engonga LC (2019) Medicinal plants used in management of cancer and other related diseases in Woleu-Ntem province, Gabon. Eur J Integr Med 29:100924.

49. Ochoa JL, Yarnitsky D (1994) The triple cold syndrome. Cold hyperalgesia, cold hypoaesthesia and cold skin in peripheral nerve disease. Brain 117: 185-197.

50. Padmanabhan P, Jangle SN (2012) Evaluation of in-vitro antiinflammatory activity of herbal preparation, a combination of four medicinal plants. Int j basic appl med 2(1):109-116.

51. Park BY, Park SH, Kim WM, Yoon MH, Lee HG (2010) Antinociceptive effect of Memantine and morphine on vincristine induced peripheral neuropathy in rats. Korean J Pain 23: 179-185.

52. Raguenez-Viotte G, Lahouel M, Ducastelle TH, Morin JP, Fillastre JP (1988) CNU adriamycin association induces earlier and more server nephropathy in rats. Arch. Toxicol 61(4): 282-291.

53. Rahman MM, Reza ASMA, Khan MA, Sujon KM, Sharmin R, Rashid M, Sadik MG, Reza MA, Tsukahara T, Capasso R, Mosaddik A, Gobe C, Alam AK (2021) Unfolding the Apoptotic Mechanism of Antioxidant Enriched-Leaves of Tabebuia pallida (Lindl.) Miers in EAC Cells and Mouse Model. $J$ Ethnopharmaco/ 114297.

54. Ribeiro RA, Vale ML, Thomazzi SM, Paschoalato AB, Poole S, Ferreira SH, Cunha FQ (2000) Involvement of resident macrophages and mast cells in the writhing nociceptive response induced by zymosan and acetic acid in mice. Eur. J. Pharmacol387: 111-118.

55. Schwartz EL (2009) Antivascular actions of microtubule binding drugs. Clin. Cancer Res 15:25942601.

56. Scripture CD, Figg WD, Sparreboom A (2006) Peripheral neuropathy induced by paclitaxel: recent insights and future perspectives. Curr Neuropharmacol 4:165-172.

57. Siau C, Xiao W, Bennett GJ (2006) Paclitaxel- and vincristine-evoked painful peripheral neuropathies: loss of epidermal innervation and activation of Langerhans cells. Exp. Neurol 201: 507-514.

58. Silva JHCE, Ferreira RS, Pereira EP, Braga-de-Souza S, Almeida MMA, Santos CCD, Butt AM, Caiazzo E, Capasso R, Silva VDAD, Costa SL (2020) <i>Amburana cearensis</i>: Pharmacological and Neuroprotective Effects of Its Compounds. Molecules 25(15):3394.

59. Singh VP, Chandrashekhar SP, Shrinivas KK (2005) Differential effect of zileuton, a 5-lipoxygenase inhibitor, against nociceptive paradigms in mice and rats. Pharmacol. Biochem. Behav 81: 433-439.

60. Sinha AK (1972) Colorimetric assay of catalase. Annu. Rev. Biochem 47:389-394.

61. Thomas E, Peat G, Harris L, Wilkie R, Croft PR (2004) The prevalence of pain and pain interference in a general population of older adults: cross selectional findings from the North Staffordshire Osteoathritis Project (NorStop). Pain 110(1-2): 361-368. 
62. Uddin Chy MN, Adnan M, Chowdhury MR, Pagano E, Kamal ATMM, Oh KK, Cho DH, Capasso R (2021) Central and peripheral pain intervention by Ophiorrhiza rugosa leaves: Potential underlying mechanisms and insight into the role of pain modulators. J Ethnopharmacol 276: 114182.

63. Van den Bent MJ (2005) Prevention of chemotherapy-induced neuropathy: leukemia inhibitory factor. Clin Cancer Res 11: 1691-1693.

64. Vieira G, Cavalli J, Gonçalves ECD, Braga SF, Ferreira RS, Santos ARS, Cola M, Raposo NRB, Capasso R, Dutra RC (2020) Antidepressant-Like Effect of Terpineol in an Inflammatory Model of Depression: Involvement of the Cannabinoid System and D2 Dopamine Receptor. Biomolecules 10(5): 792.

65. Viji V, Helen A (2008) Inhibition of lipoxygenases and cyclooxygenase-2 enzymes by extracts isolated from Bacopa monniera (L.) Wettst. J Ethnopharmacol 118(2): 305-311.

66. Vogel HG, Vogel WH (1997) Drug discovery and evaluation. Pharmacological assays," Springer, Berlin, 402-403.

67. Wang MS, Wu Y, Culver DG, Glass JD (2000) Pathogenesis of axonal degeneration: parallels between Wallerian degeneration and vincristine neuropathy. J. Neuropathol. Exp. Neurol 59:599-606.

68. Wilbur KM, Bernheim F, Shapiro OW (1949) Determination of lipid peroxidation. Arch Biochem Biophys 24:305-310.

69. Windebank AJ (1999) Chemotherapeutic neuropathy. Curr Opin Neuro/ 12: 565-571.

\section{Figures}

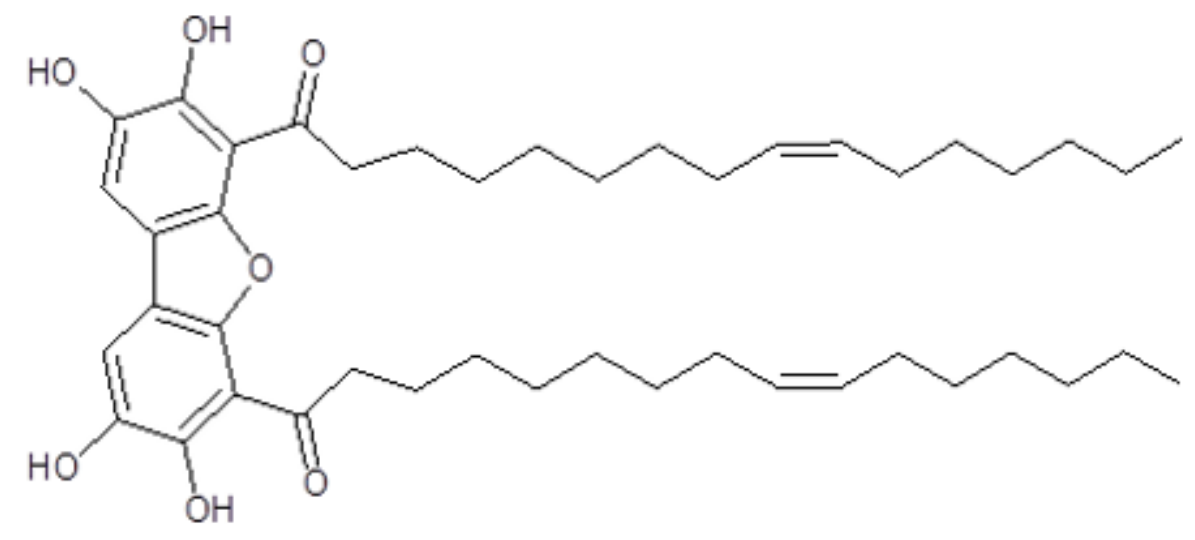

\section{Figure 1}

Structure of new dibenzofuran derivative: Scyphocephalione A 


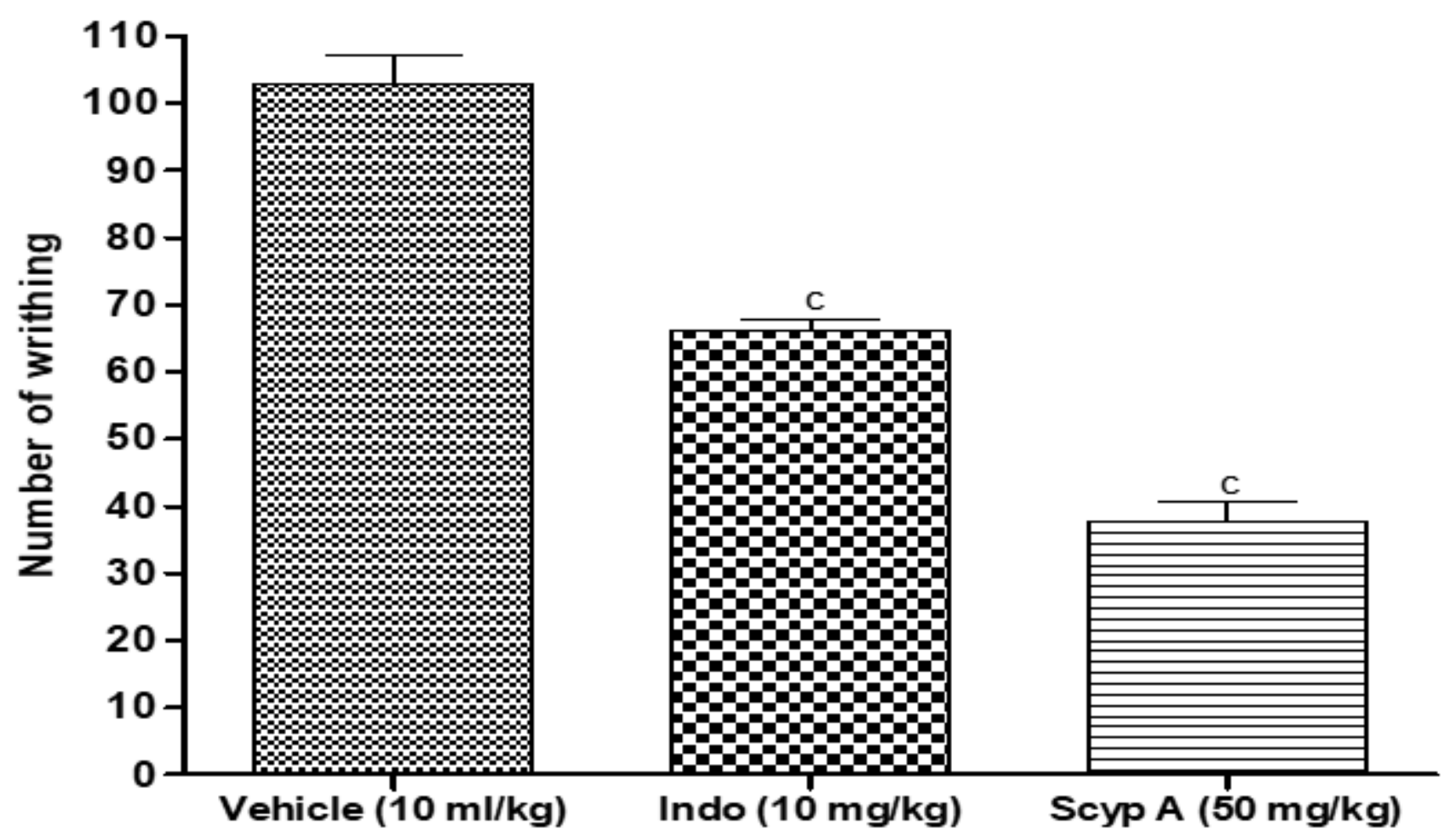

Figure 2

Effects of Scyphocephalione A (Scyp A) on acetic acid-induced pain in mice. Each bar represents the mean \pm S.E.M., $n=6{ }^{~}{ }^{c} p<0.001$ vs. Vehicle (one-way ANOVA followed by Tukey's post-test). Indo: Indomethacin. 


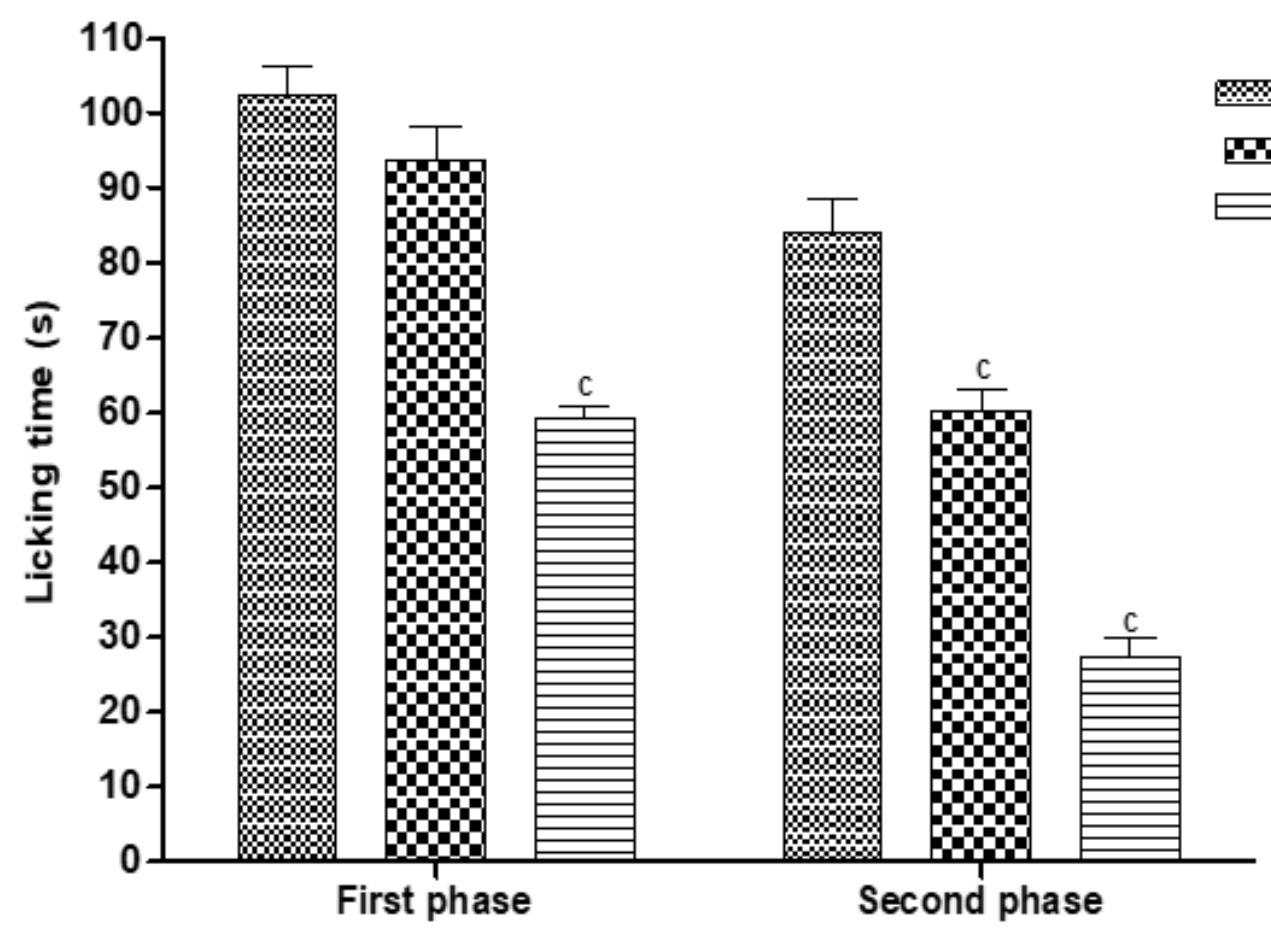

Figure 3

Effects of Scyphocephalione A on formalin-induced pain in mice. Each bar represents the mean \pm S.E.M., $n=6 .{ }^{c} p<0.001$ vs. Vehicle (one-way ANOVA followed by Tukey's post-test). 

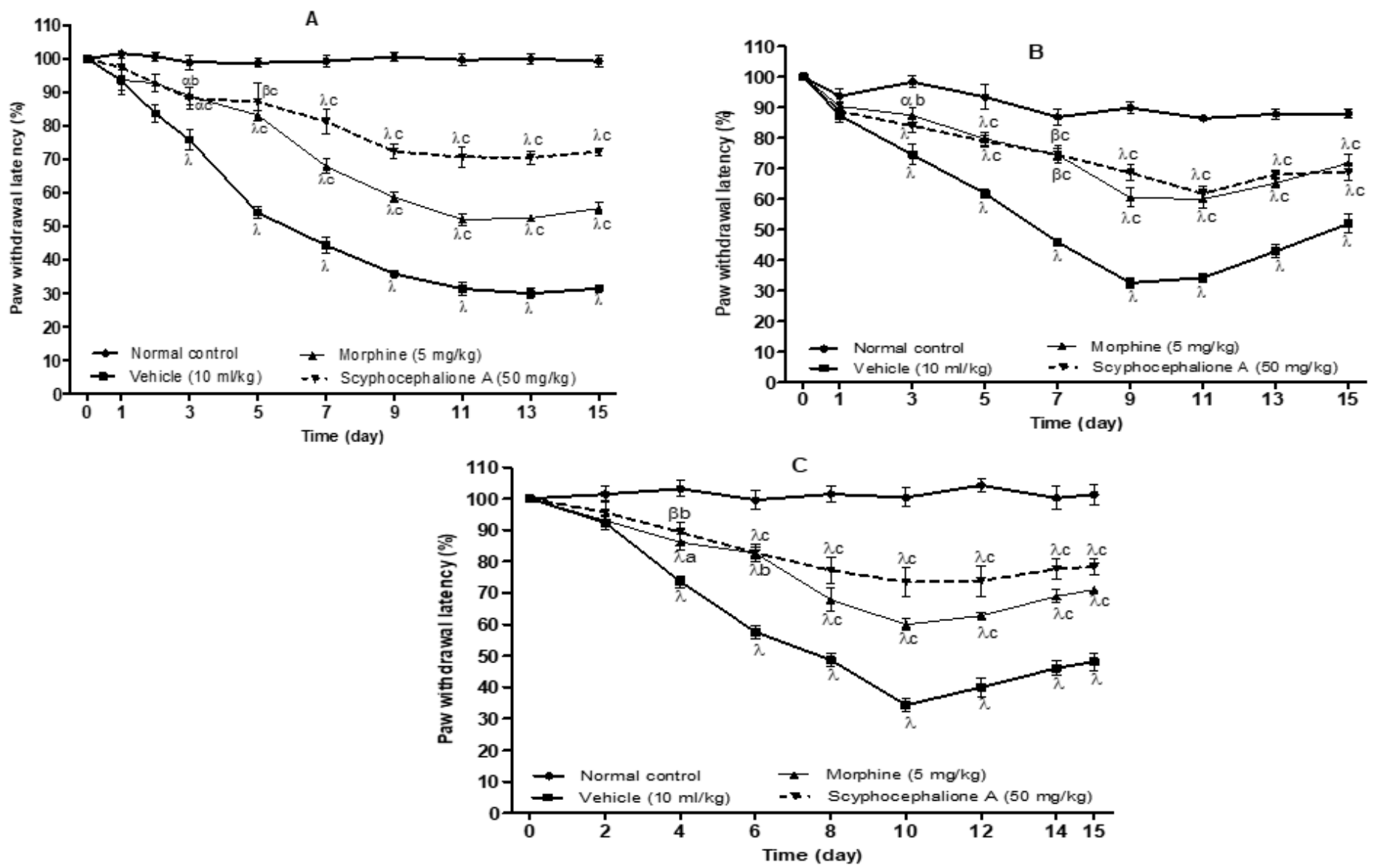

Figure 4

Effect of Scyphocephalione A on mechanical hyperalgesia (A), thermal hyperalgesia (B) and cold allodynia $(C)$ in vincristine-induced neuropathic pain. Data were expressed as mean \pm S.E.M., $n=6$. ${ }^{a} p<0.05 ;{ }^{\beta} p<0.01 ; \gamma_{p}<0.001$ vs. Normal control; ${ }^{b} p<0.01 ;{ }^{c} p<0.001$ vs. Vehicle (one-way ANOVA followed by Bonferroni post-test). 